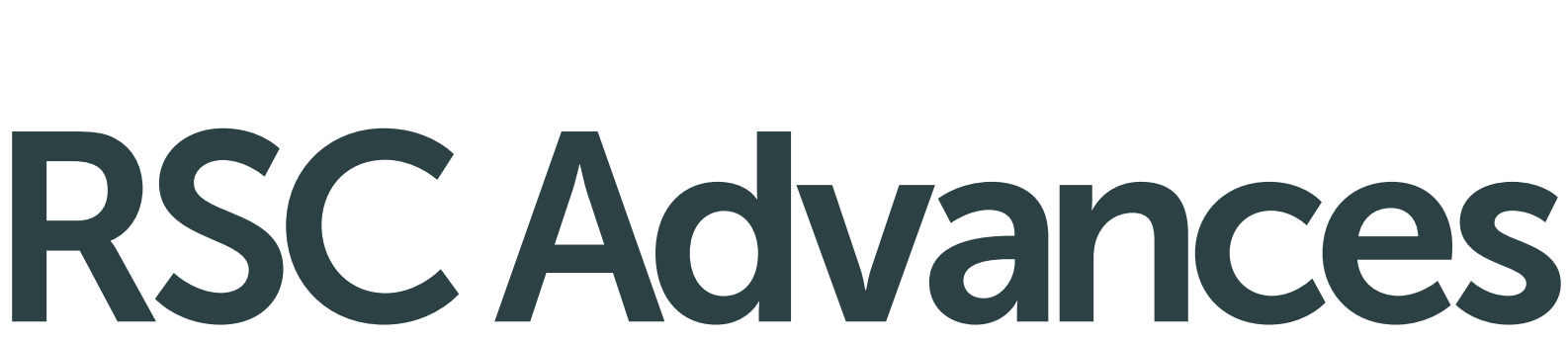

This article can be cited before page numbers have been issued, to do this please use: A. Valdés, C. Mellinas, M. Ramos, N. Burgos, A. Jiménez and M. C. Garrigós, RSC Adv., 2015, DOI:
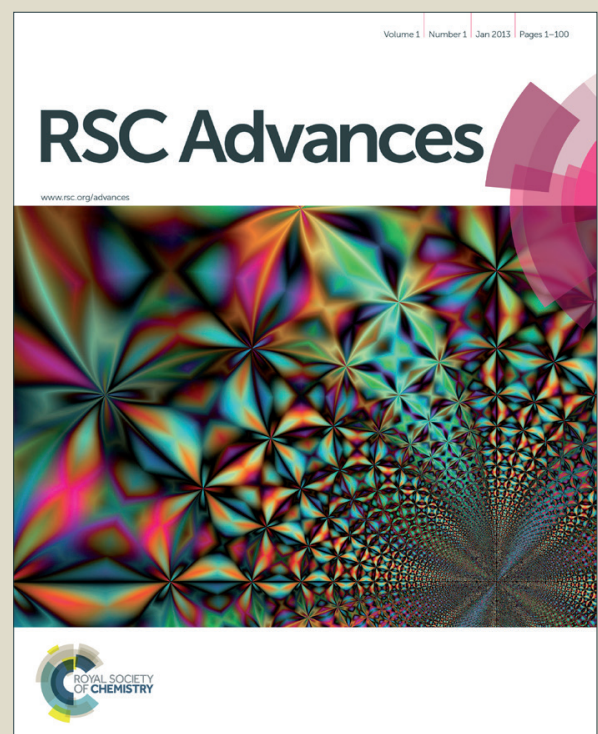

This is an Accepted Manuscript, which has been through the Royal Society of Chemistry peer review process and has been accepted for publication.

Accepted Manuscripts are published online shortly after acceptance, before technical editing, formatting and proof reading. Using this free service, authors can make their results available to the community, in citable form, before we publish the edited article. This Accepted Manuscript will be replaced by the edited, formatted and paginated article as soon as this is available.

You can find more information about Accepted Manuscripts in the Information for Authors.

Please note that technical editing may introduce minor changes to the text and/or graphics, which may alter content. The journal's standard Terms \& Conditions and the Ethical guidelines still apply. In no event shall the Royal Society of Chemistry be held responsible for any errors or omissions in this Accepted Manuscript or any consequences arising from the use of any information it contains. 


\title{
Use of herbs, spices and their bioactive compounds in active food packaging
}

\author{
A. Valdés, A.C. Mellinas, M. Ramos, N. Burgos, A. Jiménez, M.C. Garrigós \\ University of Alicante, Dpt. Analytical Chemistry, Nutrition \& Food Sciences, 03690, San Vicente del Raspeig, \\ Spain
}

\begin{abstract}
The increasing interest and society demand on the use of natural, biodegradable and renewable resources has increased in the last few years. In addition, food producers and consumers have improved their requirements in the quality of processed food, particularly in the field of increasing shelf-life while preserving organoleptic and nutritional properties. Active packaging technologies have greatly developed in the last decade by trying to satisfy the need of long-life processed food by addition of antioxidant/antimicrobial components to the packaging material. These components are intended to be released in a controlled way to food. These raising trends have been reflected in the field of food packaging by the use of chemicals extracted and obtained from plants in active packaging formulations. Herbs and spices have shown great potential to be used as renewable, biodegradable and valuable sources of chemicals, such as polyphenols, with high antioxidant/antimicrobial performance. This review aims to present the last published work in this area.
\end{abstract}

\section{Introduction}

It is well known that antioxidants are present in many plants as a way of defense to oxidative degradation coming for the environment. These bio-based and natural antioxidants have improved their use in food-related applications by their positive contributions to human health. Many plants have been considered potential antioxidants sources and some of them have been studied in recent years. In this context, numerous herbs and spices are the most important and studied targets in the search for natural antioxidants ${ }^{1}$. The terms 'herbs' and 
'spices' have more than one definition in common language, but the most commonly usedevarecle Online those to consider herbs as obtained from the green parts of plants, such as stem and leaves, while spices are usually obtained from the bark, roots, seeds or flowers. Most of the common spices are usually extracted from plants grown in warm or tropical climates while herbal plants can be grown in nearly all conditions and geographical areas around the world. In addition, spices have more intense taste and are used in small amounts ${ }^{2}$. Based on data reported by the Food and Agriculture Organization of the United Nations (FAO), the worldwide spices production has increased significantly in the last years ${ }^{3}$ whereas the global production of herbs has not been reported in the literature.

Since ancient times, herbs and spices have been extensively used to enhance or improve the flavour of food and by their preservative properties ${ }^{4}$. Several popular herbs and spices are known to have beneficial effects for human health, including digestive stimulant, antiinflammatory, antimicrobial, antioxidant and anti-carcinogenic activities, which are mostly attributed to polyphenols present in their chemical composition. Moreover, other volatile constituents in herbs and spices (particularly essential oils) can also contribute to the plant's biological activity, resulting in benefits for human health. In general terms, essential oils are chemically constituted by more than 70 different compounds, mostly polyphenols, terpenes, monoterpenes and sesquiterpenes, some of them representing more than $85 \%$ of the total oil content ${ }^{5}$. Essential oils and their components are gaining attention by their wide acceptance by consumers and the possibility of exploitation for potential multi-purpose functional uses. Phytochemicals extracted from various herbs and spices, including polyphenols, flavonoids, flavonols, tannins, and terpenoids, could help to minimise tumour development by inhibiting the initiation and promotion of carcinogenesis, inducing tumour cell differentiation and apoptosis, while suppressing tumour angiogenesis. They are also able to prevent and reverse many of the processes that underlie chronic diseases. These phytochemicals can be broadly 
classified as carotenoids, phenolics, alkaloids, nitrogen-containing compgunds, Viandidcle Online organosulfur compounds ${ }^{6}$. Some studies have been recently reported to state the presence and activity of antioxidants in herbs, to determine their total phenolic contents and to relate the total antioxidant and antimicrobial activities of methanolic extracts, infusions and decoctions of several plants; such as peppermint, thyme, lemon balm, basil, rosemary and sage ${ }^{6-7}$.

On the other hand, antioxidants present in spices have gained importance by their role in the prevention of atherogenesis. Although spices have been recognized by their beneficial health effects and have been used in traditional medicine since ancient times, their attributes in health protection have been experimentally verified only in the last three decades. In this sense, the antioxidant effects of turmeric/curcumin, clove/eugenol, onion, garlic, ginger/gingerol, red pepper/capsaicin, black pepper/piperine and fenugreek, have been recently reviewed ${ }^{8}$.

Beneficial effects of chemicals obtained from herbs and spices can be used not only directly into food but also in packaging materials to increase food shelf-life and quality. In recent years, the increase in consumer's demand for minimally processed foods, the change in retail and distribution practices associated with global markets, new product logistics and distribution trends (such as on-line shopping), automatic handling systems and strict requirements regarding consumer's health and safety have been the major driving force for innovation in food packaging technologies 9 . In this context, packaging of fat food is a particular issue, since lipid oxidation after microbial growth is the main cause of food spoilage $^{10}$. In particular, food with high content in poly-unsaturated fatty acids is more prone to oxidative deterioration resulting in the development of off-flavours, such as toxic aldehydes, and rendering products unacceptable for human consumption by their loss in nutritional quality ${ }^{11}$. The use of active packaging systems with antioxidant activity is a promising approach to improve food quality by the incorporation of antioxidant agents to the 
packaging material improving the stability of oxidation-sensitive food. However the usiew dfcle Online synthetic antioxidants in these active systems is questioned due to potential toxicological risks, resulting in requirements for strict controls. The alternative based on the use of natural antioxidants, particularly polyphenols, extracted from plants and essential oils from herbs and spices $^{12}$ and from agricultural by-products ${ }^{13}$ is one of the current trending topics in food packaging research. In this sense, natural extracts have been incorporated into plastic packaging materials in order to achieve antioxidant properties. For instance, Li et al. ${ }^{14}$ developed active gelatin films containing natural antioxidants extracted from different sources (green tea, grape seed polyphenols, grape seed proanthocyanidins, ginger and gingko leaf) for food packaging applications, showing different effects on the food packaged depending on the incorporated extract. Among them, the gingko leaf extract induced the highest radicalscavenging activity whereas the green tea extract resulted in increased protection against moisture. Quince seed mucilage films containing oregano essential oils were prepared and their antioxidant properties were evaluated by Jouki et al. ${ }^{15}$. These films exhibited high level of radical-scavenging activity (45, 57 and $61 \%$ for $1,1.5$ and 2 wt $\%$ of essential oils, respectively). In an interesting work recently reported by Castro et al. ${ }^{16}$, good feasibility of catechins and quercetin released from green tea natural extracts incorporated into polypropylene films was observed.

Several different methods have been proposed to determine the antioxidant performance of active packaging systems. Some of them are based on measuring the degree of lipid oxidation of food in direct contact with packaging materials. Several parameters, such as peroxide index, conjugated dienes, conjugated triene hydroperoxides, free fatty acids, thiobarbituric acid index and p-anisidine value (AV) can be determined to assess lipid hydrolysis and primary and secondary lipid oxidation in fat food. In addition, the antioxidant activity provided by films for food packaging can be evaluated by measuring the radical scavenging 
ability in food simulants. Several procedures have been proposed, most of them basedewdidicle Online producing and determining oxidative free-radicals, to evaluate the antioxidant properties of additives used in packaging materials. This is the case of oxygen radical absorbance capacities (ORAC), ferric reducing antioxidant power (FRAP), ABTS and DPPH tests ${ }^{17}$.

Some studies have been published on the antimicrobial performance of essential oils extracted from plants against food-borne pathogens. Since essential oils are rich in volatile terpenoids and phenolics, they show high potential to inhibit a wide spectrum of microorganisms. The active components of plant essential oils are able to inhibit microorganisms' proliferation through disturbance of the cytoplasmic membrane, disrupting the proton motive force, electron flow, active transport and inhibition of protein synthesis ${ }^{18}$.

Antimicrobial and/or antioxidant active packaging systems are getting attention from food and packaging industries due to the increasing consumer demands for minimally processed and preservative-free food products. Some plastic films allow the controlled release of additives onto food to cover the whole storage and distribution operations, while limiting undesirable effects in flavour and taste. A raising trend in the use of antimicrobial additives, such as those derived from essential oils, to minimise contamination in different kind of food, such as meat, fruits and vegetables, has been reported and will be discussed in this review article. For instance, Ramos et al. reported the development of antimicrobial active films based on polypropylene by incorporating thymol and carvacrol at three different concentrations $(4,6$ and $8 \mathrm{wt} \%)$ demonstrating their potential to be used as active additives ${ }^{19}$. Pereira de Abreu et al. ${ }^{20}$ reported the potential use of films containing antioxidant extracts from barley husks for the commercialization of frozen cod fillets and the effect on lipid oxidation during prolonged frozen storage. This increasing interest in the use of natural extracts obtained from plants in active packaging technologies is the main reason of this 
review, where the current situation in the potential use of herbs, spices and their bioaktirsecle Online compounds in antioxidant and antimicrobial active food packaging systems is discussed.

\section{Herbs}

The antioxidant/antimicrobial properties of herbs have been known since ancient times and they have been used in many applications, such as traditional medicine, food preservation and others. But the raising trend for the use of active packaging in processed food has resulted in new applications of herbs and/or extracted chemicals in food technology. It is known that antimicrobial/antioxidant agents can be incorporated directly into the active packaging systems (either as aqueous or ethanolic extracts). Some examples are summarized in Table 1.

Table 1. Examples of the direct incorporation of herb extracts into polymer matrices.

\begin{tabular}{lllc}
\hline Herb extract & Polymer & Effect on food packaging & References \\
\hline Ginseng & LDPE, PVC & Antimicrobial & 22 \\
& Alginate-based & Antioxidant & 41 \\
Rosemary & LDPE & Antioxidant & 23 \\
& LDPE & Lipid oxidation & $24-25$ \\
& PCL, methylcellulose & Antimicrobial & 42 \\
Murta & Carboxymethylcellulose & Antioxidant/ Antimicrobial & $12,43,44$ \\
Green tea & Fish skin gelatin & Antioxidant & 30 \\
& Silver carp skin gelatin & Antioxidant & 31 \\
& Multilayer PET/PE/EVOH/PE & Antioxidant/Antimicrobial & 45 \\
& EVOH & Antioxidant & 46 \\
& Fish skin gelatin & Antioxidant & 30 \\
& Agar-fish gelatin & Antioxidant & 32 \\
& EVOH & Lipid oxidation & 47 \\
Mint & Agar with glycerol & Antimicrobial & 33 \\
\hline Chingko leaf & Fish skin gelatin & Lipid oxidation & 35,36 \\
& Chitosan and polyvinyl alcohol & Antioxidant /Antimicrobial & 21 \\
\hline
\end{tabular}


Among them, green tea has been considered for years as a good source of polyphetioglficic Online compounds. Catechins (also known as flavanols), including epicatechin, epigallocatechin, epicatechin gallate, epigallocatechin gallate, catechin, gallocatechin gallate, catechin gallate, and gallocatechin, are the dominant phenolic compounds in tea leaves and most of them have been extracted from green tea leaves and other parts of the plant ${ }^{21}$.

Some commodity polymers such as low density polyethylene (LDPE) $)^{22-26}$, poly(vinyl chloride) $(\mathrm{PVC})^{22}$ and polypropylene $(\mathrm{PP})^{27-29}$ have been tested as adequate matrices to host different herb extracts. But in recent years biopolymers based on starch, cellulose derivatives, chitosan/chitin, gums, proteins obtained from animal or plant-sources, and lipids have emerged as environmentally-friendly alternatives to synthetic polymers as carriers of herb extracts (Table 1). Biopolymers could be processed by wet methods using water and other solvents, avoiding the degradation and loss of volatile active compounds in the final material due to the severe thermo-mechanical conditions applied in conventional techniques for polymer processing (extrusion, injection, blow molding and heat pressing). These biomaterials show additional advantages, such as their biocompatibility, edibility, barrier to moisture and/or gases, non-toxicity, mechanical integrity and relatively low cost. ${ }^{12}$ Fish gelatin $^{30-31,32,33-34}$ and chitosan ${ }^{35-36-40}$ have been widely used as biopolymer matrices by their own intrinsic antioxidant activity getting synergies with natural additives.

Different methods have been proposed to evaluate the antioxidant effectiveness of active materials ${ }^{17}$ directly in food or food simulants. The antioxidant activity provided by polymer films can be evaluated by measuring the radical scavenging ability in food simulants, by using the DPPH (2,2-diphenyl-1-picrylhydrazyl) test $^{41-23,30-31,46,47,36,21}$. Other similar tests were based on the ferric reducing antioxidant power (FRAP) ${ }^{32}$ and the antioxidant activity evaluated by complexation of 2,2-azino-bis-3-ethylbenzothiazoline-6-sulfonic acid $(\mathrm{ABTS})^{44,46-32}$. 
Other test methods are based on the measurement of the degree of lipid oxidation, particutarivicle Online by the determination of the initial autoxidation products, i.e. hydroperoxides, which decompose to low molecular-weight compounds resulting in the development of rancid flavours and odours ${ }^{49}$. Frequently, both the primary and secondary oxidation products are monitored by the peroxide and TBAR indices ${ }^{22,23-24,47,48}$ in shelf-life assays directly applied to food.

In a recent report, authors have not only incorporated aqueous extracts obtained from herbs to polymer matrices but also in the form of volatile essential oils (EOs), normally found in special cells or group of cells present in leaves and stems, and commonly concentrated in leaves, bark or fruits ${ }^{50}$. Some results in the use of EOs extracted from herbs are presented in Table 2.

Oregano is one of the most studied plants by its high antioxidant and antimicrobial properties $^{51,40}$. Oregano is a popular culinary herb with high content in EOs containing terpenoids, mainly the monoterpenoid phenols of thymol (5-methyl-2-[1-methylethyl] phenol) and carvacrol (5-isopropyl-2-methyl phenol) ${ }^{50}$. One important feature of the EOs obtained from oregano is their high antimicrobial activity, which is usually determined by the agar plate diffusion method, where the inhibition on solid media was used to determine the antimicrobial effects of active films against different bacteria ${ }^{26}$. Other studies have highlighted the antimicrobial activity of food EOs directly on food, such as meat or fish ${ }^{52,53}$. Oregano and other herbs have shown good antimicrobial performance depending on the type of food bacteria. For example, oregano EOs have been reported as effective against Grampositive bacteria, such as Staphylococcus aureus, Bacillus cereus, Streptococcus mutans, L.monocytogenes and Enterococcus faecalis; as well as against Gram-negative bacteria, such as Escherichia coli and Salmonella enterica subsp ${ }^{54,55}$. Results showed positive inhibition for EOs concentrations higher than $5 \%(\mathrm{w} / \mathrm{w})$ for all bacteria ${ }^{27,54,55-52}$. 
Table 2. Examples of the incorporation of essential oils from herbs into polymer matrickess Article Online

\begin{tabular}{|c|c|c|c|}
\hline Essential oil & Polymer & Effect on food packaging & References \\
\hline \multirow[t]{2}{*}{ Zataria Multiflora } & Kappa-carrageenan (KC) & Antimicrobial & $56-57$ \\
\hline & $\begin{array}{l}\text { Soluble soybean } \\
\text { polysaccharide }\end{array}$ & Antioxidant/Antimicrobial & 58 \\
\hline Satureja hortensis & $\mathrm{KC}$ & Antioxidant/Antimicrobial & 59 \\
\hline \multirow[t]{2}{*}{ Mentha pulegium } & $\mathrm{KC}$ & Antioxidant/Antimicrobial & 56 \\
\hline & $\begin{array}{l}\text { Soluble soybean } \\
\text { polysaccharide }\end{array}$ & Antioxidant/Antimicrobial & 58 \\
\hline \multirow[t]{14}{*}{ Oregano } & $\begin{array}{l}\text { Ethylene vinyl alcohol } \\
\text { copolymer }\end{array}$ & Antioxidant/Antimicrobial & 51 \\
\hline & $\begin{array}{l}\text { PET } \\
\text { Mucilage }\end{array}$ & $\begin{array}{l}\text { Antimicrobial } \\
\text { Antioxidant/Antimicrobial }\end{array}$ & $\begin{array}{l}27 \\
60\end{array}$ \\
\hline & $\begin{array}{l}\text { Thermoplastic starch with } \\
\text { poly (butylene adipate-co- } \\
\text { terephthalate) }\end{array}$ & Antioxidant/Antimicrobial & 61 \\
\hline & Chitosan & Antioxidant/Antimicrobial & 54 \\
\hline & $\mathrm{PP}$ & Antimicrobial & 27 \\
\hline & Methylcellulose & Antimicrobial & 62 \\
\hline & $\begin{array}{l}\text { PP } \\
\text { Polyvinyl alcohol (PVA) }\end{array}$ & $\begin{array}{l}\text { Insect-repellent } \\
\text { Antimicrobial }\end{array}$ & $\begin{array}{l}28 \\
55\end{array}$ \\
\hline & $\mathrm{PP} / \mathrm{EVOH}$ & Antimicrobial & $52-63$ \\
\hline & Multilayer PET/PE/EVOH/PE & Antioxidant/Antimicrobial & 45 \\
\hline & Isolated soy protein & Antioxidant & 40 \\
\hline & $\mathrm{PP}$ & Antifungal & 29 \\
\hline & LDPE & Antimicrobial & 26 \\
\hline & PLA-CNC & Antimicrobial & 53 \\
\hline & Cellulose and protein isolate & Antimicrobial & 64 \\
\hline Green tea & $\begin{array}{l}\text { Ethylene vinyl alcohol } \\
\text { copolymer (EVOH) }\end{array}$ & Antioxidant/Antimicrobial & 51 \\
\hline \multirow[t]{2}{*}{ Rosemary } & $\begin{array}{l}\text { PP } \\
\text { Cellulose acetate }\end{array}$ & $\begin{array}{l}\text { Insect-repellent } \\
\text { Antimicrobial }\end{array}$ & $\begin{array}{l}28 \\
65\end{array}$ \\
\hline & Chitosan & Antioxidant/Antimicrobial & $37-38$ \\
\hline Sage & Cellulose and protein isolate & Antimicrobial & 64 \\
\hline Basil & Isolated fish skin gelatin & Antimicrobial & 34 \\
\hline Citronella & $\mathrm{PP}$ & Insect-repellent & 28 \\
\hline \multirow[t]{3}{*}{ Thyme } & Isolated soy protein & Antioxidant & 40 \\
\hline & Pectin & Antimicrobial & 66 \\
\hline & Chitosan & Antimicrobial & 39 \\
\hline
\end{tabular}

\section{Spices}

Spices have been traditionally used as food additives to improve their organoleptic characteristics as well as to extend shelf-life by the inhibition of pathogenic bacteria, yeast 
and moulds and the reduction of lipid oxidation, which is associated to the presendiew ffcle Online $^{\circ}$ terpenoids, flavonoids and phenolic compounds ${ }^{67-68}$. Therefore, the use of spice extracts as active agents in food packaging has been suggested and studied since they provide antioxidant and antimicrobial properties to packaging materials ${ }^{69}$ acting as potential alternatives to food synthetic preservatives ${ }^{70}$. The bioactive effects of the main spice extracts incorporated to food packaging films or coatings in the last few years are summarized in Table 3.

Spice extracts have been usually incorporated as EOs into natural or synthetic polymers in food packaging applications. Some authors evaluated the direct incorporation of spice powders or their aqueous extracts into natural polymer matrices for food protective packaging, but no satisfactory results were reported up to now. For instance, Li et al. ${ }^{34}$ studied the effect of ginger extract (water soluble) into fish gelatins with no improvement in their antioxidant properties (measured by the DPPH radical scavenging method). In other study, Kechichian et al. ${ }^{71}$ evaluated the antimicrobial effect of cassava starch films with clove and cinnamon powders in contact with bread slices. They concluded that the antimicrobial effect of this combination of spices could not be clearly assessed since water activity of the bread slices increased considerably during storage, resulting in good conditions for microorganisms' proliferation.

As in the case of herbs, biopolymers such as starch, cellulose derivatives, chitosan, proteins or gums have been proposed as carrier matrices for spice extracts (Table 3). EOs from spices have been usually incorporated into polymer matrices by casting ${ }^{72-77}$ or surface coating ${ }^{29,55,78-}$ ${ }^{79}$. New active packaging materials consisting of self-adhesive PP labels with cinnamon EOs inside PET trays were used to extend the shelf-life in late-maturing peach fruits ${ }^{80}$. Authors reported the high decrease in the number of infected fruits after 12 days at room temperature when the active label was used (13\%), in comparison with the non-active packaged peaches $(86 \%)$ 


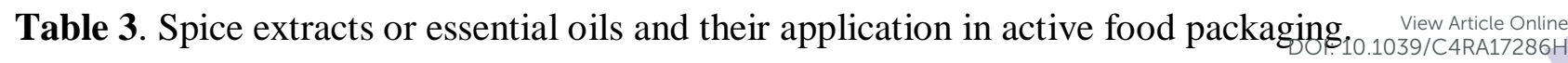

\begin{tabular}{|c|c|c|c|}
\hline Spice extract & Polymer & Effect on food packaging & References \\
\hline \multirow[t]{6}{*}{ Cinnamon EO } & Cellulose acetate & $\begin{array}{l}\text { Alteration of microstructures and } \\
\text { mechanical properties }\end{array}$ & 72 \\
\hline & PP & $\begin{array}{l}\text { Sensory evaluation: increase in shelf-life } \\
\text { from 3-10 days }\end{array}$ & 81 \\
\hline & Cassava starch & Antimicrobial & 76,77 \\
\hline & $\begin{array}{l}\text { Self-adhesive PP active } \\
\text { label inside a PET tray }\end{array}$ & $\begin{array}{l}\text { Antioxidant, antifungal and inhibition of } \\
\text { oxidative enzymes }\end{array}$ & 80 \\
\hline & Chitosan & Antimicrobial & 82 \\
\hline & $\begin{array}{l}\text { PP coated with an organic- } \\
\text { base formulation with EO }\end{array}$ & Antimicrobial, antifungal & 29 \\
\hline $\begin{array}{l}\text { Cinnamon EO } \\
\text { fortified }\end{array}$ & $\mathrm{PP}$ & Antifungal, antimycotoxigenic & 83 \\
\hline $\begin{array}{l}\text { Cinnamon EO } \\
\text { microencapsulated }\end{array}$ & LDPE-PP & $\begin{array}{l}\text { Insect-repelling agent to protect food from } \\
\text { Indian meal moth (Plodia interpunctella) }\end{array}$ & $78-79$ \\
\hline $\begin{array}{l}\text { Cinnamon EO } \\
\text { nanoliposomes }\end{array}$ & Fish gelatin & $\begin{array}{l}\text { Antimicrobial stability and decrease of } \\
\text { release rate }\end{array}$ & 84 \\
\hline Ginger extract & $\begin{array}{l}\text { Fish skin gelatin/ glycerol } \\
30 \%(\mathrm{w} / \mathrm{w})\end{array}$ & $\begin{array}{l}\text { Antioxidant, physical and mechanical } \\
\text { changes }\end{array}$ & 34 \\
\hline $\begin{array}{l}\text { Turmeric oleoresin } \\
\text { encapsulated }\end{array}$ & Gelatin:gum Arabic & Improve stability to light & 85 \\
\hline \multirow[t]{5}{*}{ Clove EO } & $\begin{array}{l}\text { Chicken feather } \\
\text { protein/gelatin }\end{array}$ & $\begin{array}{l}\text { Antimicrobial and antioxidant activity on } \\
\text { smoked salmon }\end{array}$ & 86 \\
\hline & $\begin{array}{l}\text { Fish protein } \\
\text { Cassava }\end{array}$ & Antioxidant/Antimicrobial & 74 \\
\hline & $\begin{array}{l}\text { Cassava } \\
\text { bagasse/PVA/Glycerol } \\
\text { (Trays) }\end{array}$ & Antimicrobial & 55 \\
\hline & Sunflower protein & $\begin{array}{l}\text { Antioxidant, antimicrobial and lipid } \\
\text { oxidation on sardine patties }\end{array}$ & 87 \\
\hline & Gelatin/chitosan & $\begin{array}{l}\text { Antimicrobial on fish during chilled } \\
\text { storage }\end{array}$ & 88 \\
\hline $\begin{array}{l}\text { Clove EO (coarse } \\
\text { and nanoemulsion) }\end{array}$ & Methylcellulose/PEG & Antimicrobial activity on sliced bread & 62 \\
\hline $\begin{array}{l}\text { Cinnamon and } \\
\text { lavender (EOs) }\end{array}$ & $\mathrm{NaAlg} /$ Glycerol & Antimicrobial, antifungal & 73 \\
\hline $\begin{array}{l}\text { Cinnamon and } \\
\text { cumin (EOs) }\end{array}$ & Whey protein & Antimicrobial activity on fresh beef & 75 \\
\hline $\begin{array}{l}\text { Cinnamon, clove } \\
\text { and ginger (EOs) }\end{array}$ & PP & Antioxidant & 89 \\
\hline $\begin{array}{l}\text { Cinnamon, clove } \\
\text { and red pepper } \\
\text { powders }\end{array}$ & Cassava starch & Antimicrobial effect on bread slices & 71 \\
\hline $\begin{array}{l}\text { Allspice, cinnamon } \\
\text { and clove bud EOs }\end{array}$ & Edible apple films & Antimicrobial activity & 90 \\
\hline \multirow{2}{*}{$\begin{array}{l}\text { Asian (nutmeg, } \\
\text { lemongrass and } \\
\text { citral) and Italian } \\
\text { spice EOs (oregano } \\
\text { and lemongrass) }\end{array}$} & $\begin{array}{l}\text { Methylcellulose (MC), } \\
\text { PCL/ALG }\end{array}$ & Antibacterial effect on pre-cut broccoli & 42 \\
\hline & $\mathrm{PCL} / \mathrm{MC}(\mathrm{EO}) / \mathrm{PCL}$ & Antimicrobial activity on pre-cut broccoli & 91 \\
\hline
\end{tabular}


The extraction method selected to obtain EOs from spices plays a key role in theipicie Online composition and final quality ${ }^{92}$, modifying their antimicrobial activity ${ }^{93}$. Nevertheless, the current use of EOs extracted from spices in food packaging is still limited by their volatility and low stability against oxygen and light during processing and storage. Microencapsulation technologies have emerged as a promising alternative to control the release of EOs onto food surfaces and to increase stability against environmental factors. Kim et al. ${ }^{78-79}$ developed laminated films based on PP and LDPE coated with a printing ink containing microencapsulated cinnamon EO to protect food from the Indian meal moth (Plodia interpunctella). Authors reported that these films effectively inhibited the invasion of moth larvae in cookies, milk, chocolate and caramel, acting as insect-resistant films. They observed that microencapsulation decreased the release rate of cinnamaldehyde EO and increased their thermal stability, with no effect on the tensile and moisture barrier properties of the active film. Zuanon et al. ${ }^{85}$ observed that the complex coacervation of turmeric oleoresin (a natural pigment) using gelatin and Arabic gum as wall materials was a feasible process to produce microcapsules with suitable colour, physical attributes and high curcumin retention. However, this process did not preserve the pigment under natural radiation.

Other strategies to incorporate EOs into water-soluble polymers to form antimicrobial films have been reported. Otoni et al. ${ }^{62}$ prepared coarse emulsions (1.3-1.9 $\mu \mathrm{m}$ diameter) and nanoemulsions (180-250 nm diameter) of clove bud EOs through low-speed mixing and ultrasonication, respectively, to be incorporated into methylcellulose matrices. They observed that droplet size reduction provided further improvement in antimicrobial properties against yeasts and moulds in sliced bread. In addition, low EOs contents might be used if encapsulated in smaller particles to keep antimicrobial efficiency. However, the EO emulsions reduced the rigidity and increased the extensibility of films and these effects were more pronounced for nanodroplets. Some increase in the antimicrobial stability with the 
decrease in cinnamon EOs release rate was observed for gelatin films incorporated viviteficle Online cinnamon EO nanoliposomes ${ }^{84}$. In order to minimize organoleptic effects, Bentayeb et al. ${ }^{89}$ prepared films with higher thickness and low concentration of EOs.

EOs extracted from cinnamon and cloves were studied with successful incorporation into natural and synthetic polymers, providing bioactive properties to films (Table 3). Cinnamon oil is mainly composed of cinnamaldehyde (60.4\%), with eugenol, linalool and 1,8-cineole as minor compounds ${ }^{82}$. These EOs have been reported to show antimicrobial, antibacterial, antifungal, insect-repellent and antioxidant activities ${ }^{69,94}$.

In the case of clove EOs, the major component is eugenol, with eugenyl-acetate, $\beta$ caryophyllene and 2-heptanone as minor compounds, with variable proportions depending on the type and origin of the plant and the extraction method ${ }^{95}$. Clove oil exhibited antimicrobial activity against moulds, yeasts and bacteria, and also antifungal and antioxidant properties when incorporated into natural polymers (Table 3).

The addition of spice extracts with antioxidant and/or antimicrobial properties into a polymer matrix could affect the physical, morphological, mechanical, thermal and gas barrier properties of the film. In this sense, significant decrease in tensile strength and elongation at break of films with spice extracts were reported ${ }^{34,73-74,76}$. However, Wu et al. ${ }^{84}$ studied the incorporation of cinnamon EOs to fish gelatin resulting in more flexible films. On the other hand, some positive effects related with the decrease in water solubility and water vapour permeability of films were observed by some authors ${ }^{74,76,84,87}$.

\section{Active compounds}

As previously reported, essential oils have been thoroughly evaluated in their antimicrobial, antifungal, antiviral, insecticidal and antioxidant properties, but the most innovative approaches in this area come from the use of their bioactive compounds ${ }^{12,96-98}$. For this 
reason, current trends in food packaging research include the development of active systiem based on materials able to host a variety of bioactive compounds, extracted from herbs and spices $^{98-99}$. The addition of bioactive compounds with antioxidant/antimicrobial properties directly to food or packaging materials depends primarily on their activity against the targeted microorganisms and oxidative degradation, and their ability to be released at controlled rate during storage and distribution, resulting in extension of food shelf-life ${ }^{100}$. Nevertheless, other factors, including specific activity of bioactive chemicals, resistance of microorganisms to their action, controlled release mechanisms, chemical nature of the packaged food, physical and mechanical properties of packaging materials, organoleptic properties and potential toxicity of additives should be considered to design packaging systems with bioactive compounds ${ }^{17,98}$. The mechanical, gas barrier, thermal and morphological properties of films can be altered by the incorporation of bioactive additives. In consequence, the evaluation of these properties will help to understand the interaction of polymer matrices with additives as well as to set processing parameters for fabrication of bioactive films.

Bastarrachea et al. reported a significant change in tensile properties of polymer films after the incorporation of some antimicrobials. Barrier properties were evaluated with different gases with significant effect of additives, mostly but not always negative. Authors discussed the addition of antimicrobials and their influence in permeability to gases by changing their solubility or due to the creation of pinholes in the packaging structure depending on the chemical structure of the antimicrobial agent ${ }^{101}$. In addition, some modifications in crystallinity and glass transition temperatures were observed ${ }^{19}$. Scanning electron microscopy studies helped to explain structural modifications induced by the incorporation of additives to these polymer matrices, by detecting formation of pores, thereby influencing the tensile and gas barrier properties of the film ${ }^{102}$. 
Diffusion of additive molecules through films has been also studied and mathematical modedside Online were proposed to describe the mass transfer of additive molecules and other substances through the polymer bulk to the surface. Most of these models were based on Fick's laws and helped in the assessment of compliance with specific migration limits and described the effective transport of migrating species with time ${ }^{103}$. Modifications in diffusion coefficients of additive molecules through the polymer structure can be related with formation/rupture of hydrogen bonds, hydrophobic and/or electrostatic interactions. Some authors proposed kinetic models where some high initial rates were observed with further observation of a plateau at different times and temperatures ${ }^{104-106}$. This behaviour was attributed to hydrogen bonding effects between additives and polymer matrices and/or to tortuosity effects within polymer macromolecular structures ${ }^{107}$.

Many active packaging materials have been developed in the last few years with bioactive compounds extracted from spices and herbs. Typically, in antimicrobial and antioxidant packaging systems, additives are incorporated in different ways ${ }^{108}$ : a) Incorporation by melt-blending before extrusion where a masterbatch is obtained with further injection to obtain films; b) Solvent-compounding and solution coating to prevent the loss of volatile additives ${ }^{108}$ where solutions can be incorporated to the polymer matrix as thin layers or coatings by spraying, casting or lamination after extrusion ${ }^{17,109}$; and c) encapsulation ${ }^{110}$ to permit the formation of a physical barrier between the external media and sensitive active compounds to be protected against oxidation and changes in moisture and $\mathrm{pH}$. Encapsulated microparticles can be produced by spray-drying, spray-cooling/chilling, coacervation, gelation, solvent evaporation, extrusion methods and supercritical fluid expansion ${ }^{79}$; d), grafting $^{111}$, to permit the covalent binding of active compounds to natural and synthetic polymers. 
<smiles>Cc1ccc(C(C)C)cc1O</smiles><smiles>CC(C)=CCCC(C)=CO</smiles><smiles>CC=CC=CC(=O)O</smiles><smiles>Cc1ccc(C(C)C)c(O)c1</smiles><smiles>C=CC(C)(O)CCCC(C)C</smiles><smiles>O=C(O)c1cc(O)c(O)c(O)c1</smiles><smiles>O=C(O)CC(O)(CC(=O)O)C(=O)O</smiles><smiles>[R]c1c(C)c2c(c([R1])c1O)CCC(C)(CCCC(C)CCCC(C)CCCC(C)C)O2</smiles>

Tocopherols
a: $\mathrm{R}_{1}=\mathrm{CH}_{3} \quad \mathrm{R}_{2}=\mathrm{CH}_{3}$
$\beta: \mathrm{R}_{1}=\mathrm{H} \mathrm{R} \mathrm{R}_{2}=\mathrm{CH}_{3}$
V: $\mathrm{R}_{1}=\mathrm{CH}_{3} \mathrm{R}_{2}=\mathrm{H}$
ס: $R_{1}=H R_{2}=H$

Figure 1. Main bioactive compounds used in polymer-based films.

Figure 1 summarizes the chemical structures of the main bioactive compounds incorporated into or coated onto packaging films in the last years. The most common bioactive additives are those with antioxidant performance, particularly phenols, such as carvacrol, tocopherols and thymol. These natural compounds can be found in fruits, vegetables, cereals, tea, oils, and many herbs and spices ${ }^{112}$. Their action against the lipidic auto-oxidation is based on the phenols' ability to release H-atoms from their hydroxyl groups and further reaction with 
peroxyl radicals to produce stable phenoxyl radicals to terminate lipid peroxidation d chariticle Online reactions. The efficiency of the extracted chemicals in their antioxidant activity depends on the electronic and steric effects of the phenol ring, their substituents and the strength of the hydrogen-bonding interactions between phenol and solvents ${ }^{99}$.

Manzanarez-López et al. developed new films for food packaging based on PLA with 2.58 $\mathrm{wt} \%$ of $\alpha$-tocopherol ${ }^{100}$. They evaluated the optical and thermal properties of these films as well as the kinetics of the antioxidant diffusion from the PLA matrix to ethanol and vegetable oil. Results showed that the diffusion of $\alpha$-tocopherol into oil was slower than to ethanol with 5.1 and $12.9 \%$, respectively, after 10 days of contact time. They also studied the release of $\alpha-$ tocopherol from films to soybean oil with the aim to delay the induction of oxidation in food stored at 20 and $30{ }^{\circ} \mathrm{C}^{100}$.

Another interesting alternative in the use of PLA in active packaging formulations by using casting processing was reported by Jamshidian et al. ${ }^{115}$ who obtained films with natural antioxidants including $\alpha$-tocopherol and synthetic commercial phenols, such as butylated hydroxyanisole (BHA), butylated hydroxytoluene (BHT), propyl gallate or tertbutylhydroquinone (TBHQ). Their release in different food simulants was studied to evaluate the kinetic coefficients to support the continuous control of the oxidation reactions in diverse foodstuff.

Other biopolymer matrices have been tested as host for active components. For example, edible polymer films comprise polysaccharides, lipids, proteins or blends of these macromolecules. Cellulose-based edible films, such as methylcellulose or chitosan, ${ }^{116}$ were recently proposed to develop antioxidant active packaging materials based on the incorporation of $\alpha$-tocopherol to this blend by encapsulation of this additive to the chitosan matrix $^{117}$. Other authors have proposed poly ( $\varepsilon$-caprolactone) (PCL) nanocapsule suspensions to permit a longer permanence of the additive into the polymer matrix ${ }^{118}$. 
As previously stated, carvacrol and thymol are two phenolic monoterpenes and isolinerdscle Online obtained from oregano and with high potential as antioxidant active compounds ${ }^{119}$. They have received attention due to their natural origin and broad antimicrobial and antifungal spectra against different microorganisms, high antioxidant activity and heat stability when incorporated into packaging materials ${ }^{50,120-121}$. A wide variety of polymers were used to host carvacrol and/or thymol, and different properties in these active materials were evaluated. Thermal, mechanical and optical performance in these blends showed to be competitive in comparison with common polymers used in food packaging, while the release of these additives from polymer matrices showed adequate rate to understand the transport mechanisms of these molecules to go through polymer matrices and to reach food. LDPE in combination with an organo-modified montmorillonite (MMT) and carvacrol has been proposed as a potential antimicrobial active packaging material ${ }^{122}$. These blends proved to be more effective against $E$. Coli than LDPE with just carvacrol without the addition of MMT. This effect was ascribed to the significantly higher carvacrol content permitted by the presence of the nanoclay. Similar results were obtained by Efrati et al. for nanocomposites based on LDPE with thymol and different organo-modified montmorillonites ${ }^{123}$. They found a dependence between the concentration of clay in the film and the desorption mechanism of thymol. Ramos et al. prepared PP-based nanocomposites with thymol and carvacrol, reporting that both additives were more effective against gram negative $(E$. Coli) than against gram positive $(S \text {. Areus })^{19}$ bacteria.

A wide variety of antimicrobial materials based on biopolymer matrices has been developed. Some authors based their studies in chitosan with carvacrol as antimicrobial or antioxidant agent $^{124-127}$. Different procedures were proposed to determine the antimicrobial and antioxidant activities and release in different simulants to determine their performance as materials for active food packaging. Kavoosi et al. used gelatin solutions with carvacrol at 


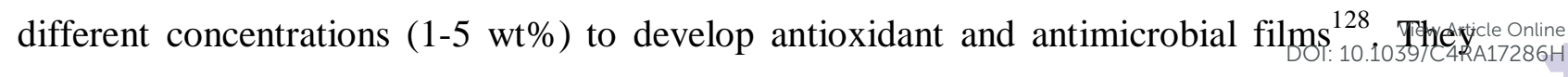
stated that these films exhibited excellent antioxidant and antibacterial properties against both gram positive and gram negative bacteria.

Thymol has been also incorporated into different matrices to enhance their antimicrobial and antioxidant performance to increase biosafety of the packed food ${ }^{129}$. Wu et al. used PLA/PCL blends prepared by solvent casting ${ }^{121}$, while Ramos et al. prepared PLA-based films by melt-

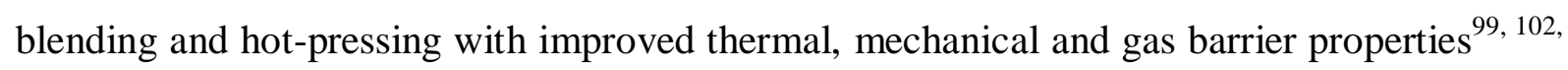
${ }^{130}$. In addition, these films showed enhanced inhibition to different food borne bacteria and excellent antioxidant capacity.

Geraniol and linalool are monoterpenes traditionally used as fragrance/flavour additives in food industry with properties to tackle infectious diseases and/or to preserve food due to their remarkable properties as insect repellent, antimicrobial, antioxidant, anti-inflammatory and anticancer $^{131-132}$. These are natural components of EOs of citronella and coriander, respectively, and they have been used to develop antimicrobial active packaging materials with evaluation of their stability and physico-mechanical and optical properties. Kayaci et al. based their studies in the development of encapsulation strategies with cyclodextrins to extend the product shelf-life by improving the additives stability ${ }^{124}$. Thermogravimetric analysis results showed higher thermal stability in geraniol complexed with cyclodextrins than in pure geraniol permitting an easier incorporation into the polymer matrices. Linalool at relatively low $(0.75 \pm 0.08 \mathrm{wt} \%)$, medium $(1.08 \pm 0.04 \mathrm{wt} \%)$ and high concentrations $(3.20 \pm 0.29 \mathrm{wt} \%)$ were incorporated into thermoplastic starch (TPS) ${ }^{133}$. Authors reported that the direct incorporation of this additive into TPS films did not adversely affect the film properties, particularly at low linalool concentration. These studies need to go deeper into antimicrobial effect of these films, but some preliminary studies showed their potential application in functional food packaging and other food or medical related applications. 
Organic acids, such as benzoic, gallic, citric and sorbic, also showed strong antimicrobibiạcle Online and/or antioxidant activities and they have been used as food preservatives ${ }^{134}$. They have been also proposed as active additives in food packaging materials, since they have been included in a positive list by the Food and Drug Administration (FDA) and they are compounds generally recognized as safe (GRAS) ${ }^{135-136}$. A recent study showed that the incorporation of citric acid to linear LDPE, besides showing enhanced antimicrobial and antioxidant properties in meat samples stored under refrigeration conditions, could also act as plasticizer in films ${ }^{136}$. Sorbic and benzoic acids and their salts are also active against yeast, moulds and many bacteria $^{116}$. Da Rocha et al. found that protein-based edible films with $1.50 \mathrm{wt} \%$ of sorbic or benzoic acids inhibited the proliferation of E. Coli O157:H7, Listeria Monocytogenes and Salmonella Enteritidis; but they did not inhibit the growing of S. Aureus ${ }^{135}$. Manab et al. showed that benzoic acid incorporated to whey protein-based films significantly inhibited $E$. Coli and Salmonellas ${ }^{137}$.

\section{Final remarks}

The rising number of studies presented in the last years on the incorporation of natural active additives to polymer and more specifically to biopolymer matrices has shown the great potential of these formulations to improve selected properties in food packaging materials and to protect the packaged food in a more efficient way. This review focused on studies with natural additives obtained from herbs and spices, either getting directly some of the valuable components from plants or more commonly by extraction of chemicals with antioxidant/antimicrobial properties. As a conclusion of this exhaustive study, it should be highlighted that herbs and spices have shown great potential as sources of highly valuable compounds to be further used in different applications, particularly in active food packaging. 
Nevertheless deeper insight in the interactions of these additives with biopolymer matrideses fisce Online necessary and further studies are currently on-going.

\section{Acknowledgements}

Authors would like to thank the Spanish Ministry of Economy and Competitiveness (MINECO) by their financial support (Project MAT2011-28648-C02-01). Moreover, Marina Ramos would like to thank University of Alicante (Spain) for UAFPU2011-48539721S predoctoral research grant. 


\section{References}

1. Y. R. N. Manuel Viuda-Martos, Elena Sánchez Zapata,Juana Fernández-López and José A. Pérez-Álvarez, Flavour Fragr. J. , 2010, 25, 13-19.

2. $\quad$ B. Ranton, ed., Handbook of herbs and spices CRC Press. , 2004.

3. FAO, Last access December 2014.

4. A. Vallverdú-Queralt, J. Regueiro, M. Martínez-Huélamo, J. F. Rinaldi Alvarenga, L. N. Leal and R. M. Lamuela-Raventos, Food Chemistry, 2014, 154, 299-307.

5. T. Kulisic, A. Radonic, V. Katalinic and M. Milos, Food Chemistry, 2004, 85, 633640.

6. R. I. Shobha, C. U. Rajeshwari and B. Andallu, in Cancer, ed. V. Preedy, Academic Press, San Diego, 2014, pp. 91-100.

7. S. Kamiloglu, E. Capanoglu, O. Yilmaz, A. F. Duran and D. Boyacioglu, Qual. Assur. Saf. Crops Foods, 2014, 6, 151-158.

8. K. Srinivasan, Critical Reviews in Food Science and Nutrition, 2014, 54, 352-372.

9. P. Singh, A. A. Wani and S. Saengerlaub, Nutrition and Food Science, 2011, 41, 249260.

10. P. Sanchez-Bel, I. Egea, M. T. Pretel, F. B. Flores, F. Romojaro and M. C. MartínezMadrid, Food Science and Technology International, 2011, 17, 529-540.

11. A. Valdés, Beltrán, A., Garrigós, M. C. , Journal of Food Science, 2013, 78, C138144.

12. A. Silva-Weiss, M. Ihl, P. J. A. Sobral, M. C. Gómez-Guillén and V. Bifani, Food Engineering Reviews, 2013, 5, 200-216.

13. A. Valdés, Mellinas, A. C., Ramos, M., Garrigós, M. C. Jiménez, and A., Frontiers in Chemistry, 2014, 2, 1-10.

14. J. H. Li, Miao, J., Wu, J. L., Chen, S. F., Zhang, Q. Q., Food Hydrocolloids, 2014, 37, 166-173.

15. M. Jouki, Yazdi, F. T., Mortazavi, S. A., Koocheki, A. , Food Hydrocolloids, 2014, 36, 9-19.

16. M. M. Castro, López, J. M., González, M. V. , Food Chemistry, 2014, 150, 119-127.

17. J. Gómez-Estaca, C. López-de-Dicastillo, P. Hernández-Muñoz, R. Catalá and R. Gavara, Trends in Food Science \& Technology, 2014, 35, 42-51.

18. S.-Y. Sung, L. T. Sin, T.-T. Tee, S.-T. Bee, A. R. Rahmat, W. A. W. A. Rahman, A.C. Tan and M. Vikhraman, Trends in Food Science \& Technology, 2013, 33, 110-123.

19. M. Ramos, A. Jiménez, M. Peltzer and M. C. Garrigós, Journal of Food Engineering, 2012, 109, 513-519.

20. D. A. Pereira de Abreu, J. Maroto, K. Villalba Rodríguez and J. M. Cruz, Journal of the Science of Food and Agriculture, 2012, 92, 427-432.

21. S. R. Kanatt, M. S. Rao, S. P. Chawla and A. Sharma, Food Hydrocolloids, 2012, 29, 290-297.

22. W. Hu, P. Xu and T. Uchino, Journal of the Science of Food and Agriculture, 2005, 85, 2475-2481.

23. L. Barbosa-Pereira, G. P. Aurrekoetxea, I. Angulo, P. Paseiro-Losada and J. M. Cruz, Meat Science, 2014, 97, 249-254.

24. T. Bolumar, M. L. Andersen and V. Orlien, Food Chemistry, 2011, 129, 1406-1412.

25. O. E. Çoban and O. P. Can, Journal of Aquatic Food Product Technology, 2013, 22, 361-370.

26. A. C. V. Solano and C. R. de Gante, Food and Bioprocess Technology, 2012, 5, 25222528.

27. V. Otero, R. Becerril, J. A. Santos, J. M. Rodríguez-Calleja, C. Nerín and M.-L. García-López, Food Control, 2014, 42, 296-302. 
28. F. Licciardello, G. Muratore, P. Suma, A. Russo and C. Nerín, Innoyatiye Foyddele Online Science and Emerging Technologies, 2013, 19, 173-180.

29. S. Manso, R. Becerril, C. Nerín and R. Gómez-Lus, Food Control, 2015, 47, 20-26.

30. J.-H. Li, J. Miao, J.-L. Wu, S.-F. Chen and Q.-Q. Zhang, Food Hydrocolloids, 2014, 37, 166-173.

31. J. Wu, S. Chen, S. Ge, J. Miao, J. Li and Q. Zhang, Food Hydrocolloids, 2013, 32, 4251.

32. B. Giménez, A. López de Lacey, E. Pérez-Santín, M. E. López-Caballero and P. Montero, Food Hydrocolloids, 2013, 30, 264-271.

33. A. M. López de Lacey, M. E. López-Caballero and P. Montero, LWT - Food Science and Technology, 2014, 55, 559-564.

34. Y. A. Arfat, S. Benjakul, T. Prodpran, P. Sumpavapol and P. Songtipya, Food Hydrocolloids, 2014, 41, 265-273.

35. U. Siripatrawan and S. Noipha, Food Hydrocolloids, 2012, 27, 102-108.

36. U. Siripatrawan and B. R. Harte, Food Hydrocolloids, 2010, 24, 770-775.

37. M. Abdollahi, M. Rezaei and G. Farzi, International Journal of Food Science and Technology, 2012, 47, 847-853.

38. M. Abdollahi, M. Rezaei and G. Farzi, Journal of Food Engineering, 2012, 111, 343350.

39. M. H. Hosseini, S. H. Razavi, S. M. A. Mousavi, S. A. S. Yasaghi and A. G. Hasansaraei, Journal of Applied Sciences, 2008, 8, 2895-2900.

40. B. Kodal Coşkun, E. Çalikoğlu, Z. Karagöz Emiroğlu and K. Candoğan, Journal of Food Quality, 2014, 37, 203-212.

41. K. Norajit, K. M. Kim and G. H. Ryu, Journal of Food Engineering, 2010, 98, 377384.

42. P. N. Takala, K. D. Vu, S. Salmieri, R. A. Khan and M. Lacroix, LWT - Food Science and Technology, 2013, 53, 499-506.

43. C. Ramírez, I. Gallegos, M. Ihl and V. Bifani, Journal of Food Engineering, 2012, 109, 424-429.

44. M. Quilaqueo Gutiérrez, I. Echeverría, M. Ihl, V. Bifani and A. N. Mauri, Carbohydrate Polymers, 2012, 87, 1495-1502.

45. J. M. Lorenzo, R. Batlle and M. Gómez, LWT - Food Science and Technology, 2014, 59, 181-188.

46. C. López De Dicastillo, C. Nerín, P. Alfaro, R. Catalá, R. Gavara and P. HernándezMuñoz, Journal of Agricultural and Food Chemistry, 2011, 59, 7832-7840.

47. C. López-de-Dicastillo, J. Gómez-Estaca, R. Catalá, R. Gavara and P. HernándezMuñoz, Food Chemistry, 2012, 131, 1376-1384.

48. K. K. N. C. L. Perazzo, A. Carlos De Vasconcelos Conceição, J. C. Pires Dos Santos, D. De Jesus Assis, C. O. Souza and J. I. Druzian, PLoS ONE, 2014, 9.

49. F. Tian, E. A. Decker and J. M. Goddard, Food and Function, 2013, 4, 669-680.

50. K. K. Kuorwel, M. J. Cran, K. Sonneveld, J. Miltz and S. W. Bigger, Journal of Food Science, 2011, 76, R164-R177.

51. V. Muriel-Galet, M. J. Cran, S. W. Bigger, P. Hernández-Muñoz and R. Gavara, Journal of Food Engineering, 2015, 149, 9-16.

52. V. Muriel-Galet, J. P. Cerisuelo, G. López-Carballo, S. Aucejo, R. Gavara and P. Hernández-Muñoz, Food Control, 2013, 30, 137-143.

53. S. Salmieri, F. Islam, R. A. Khan, F. M. Hossain, H. M. M. Ibrahim, C. Miao, W. Y. Hamad and M. Lacroix, Cellulose, 2014.

54. N. M. Hromiš, V. L. Lazić, S. L. Markov, Ž. G. Vaštag, S. Z. Popović, D. Z. Šuput and N. R. Džinić, Acta Periodica Technologica, 2014, 45, 33-43. 
55. F. Debiagi, R. K. T. Kobayashi, G. Nakazato, L. A. Panagio and S. Mali, Indystriatcle online Crops and Products, 2014, 52, 664-670.

56. S. Shojaee-Aliabadi, H. Hosseini, M. A. Mohammadifar, A. Mohammadi, M. Ghasemlou, S. M. Hosseini and R. Khaksar, Carbohydrate Polymers, 2014, 101, 582591.

57. S. Shojaee-Aliabadi, M. A. Mohammadifar, H. Hosseini, A. Mohammadi, M. Ghasemlou, S. M. Hosseini, M. Haghshenas and R. Khaksar, International Journal of Biological Macromolecules, 2014, 69, 282-289.

58. D. Salarbashi, S. Tajik, S. Shojaee-Aliabadi, M. Ghasemlou, H. Moayyed, R. Khaksar and M. S. Noghabi, Food Chemistry, 2014, 146, 614-622.

59. S. Shojaee-Aliabadi, H. Hosseini, M. A. Mohammadifar, A. Mohammadi, M. Ghasemlou, S. M. Ojagh, S. M. Hosseini and R. Khaksar, International Journal of Biological Macromolecules, 2013, 52, 116-124.

60. M. Jouki, F. T. Yazdi, S. A. Mortazavi and A. Koocheki, Food Hydrocolloids, 2014, 36, 9-19.

61. L. A. Cestari, R. C. Gaiotto, J. L. Antigo, M. R. S. Scapim, G. S. Madrona, F. Yamashita, M. S. S. Pozza and I. N. Prado, Journal of Food Science and Technology, 2014.

62. C. G. Otoni, S. F. O. Pontes, E. A. A. Medeiros and N. d. F. F. Soares, Journal of Agricultural and Food Chemistry, 2014, 62, 5214-5219.

63. V. Muriel-Galet, J. P. Cerisuelo, G. López-Carballo, M. Lara, R. Gavara and P. Hernández-Muñoz, International Journal of Food Microbiology, 2012, 157, 195-201.

64. M. Royo, I. Fernández-Pan and J. I. Maté, Journal of the Science of Food and Agriculture, 2010, 90, 1513-1519.

65. A. A. M. de Melo, R. M. Geraldine, M. F. A. Silveira, M. C. L. Torres, C. S. M. e Rezende, T. H. Fernandes and A. N. de Oliveira, Brazilian Journal of Microbiology, 2012, 43, 1419-1427.

66. P. J. P. Espitia, R. J. Avena-Bustillos, W.-X. Du, R. F. Teófilo, N. F. F. Soares and T. H. McHugh, Food Packaging and Shelf Life, 2014, 2, 38-49.

67. P. S. Negi, International Journal of Food Microbiology, 2012, 156, 7-17.

68. M. M. Tajkarimi, S. A. Ibrahim and D. O. Cliver, Food Control, 2010, 21, 1199-1218.

69. F. Sadaka, C. Nguimjeu, C. H. Brachais, I. Vroman, L. Tighzert and J. P. Couvercelle, Innovative Food Science and Emerging Technologies, 2014.

70. J. Gómez-Estaca, C. López-de-Dicastillo, P. Hernández-Muñoz, R. Catalá and R. Gavara, Trends in Food Science and Technology, 2014, 35, 42-51.

71. V. Kechichian, C. Ditchfield, P. Veiga-Santos and C. C. Tadini, LWT - Food Science and Technology, 2010, 43, 1088-1094.

72. P. J. P. Espitia, N. D. F. F. Soares, L. C. M. Botti and W. A. Silva, Macromolecular Symposia, 2011, 299-300, 199-205.

73. I. Liakos, L. Rizzello, D. J. Scurr, P. P. Pompa, I. S. Bayer and A. Athanassiou, International Journal of Pharmaceutics, 2014, 463, 137-145.

74. B. Teixeira, A. Marques, C. Pires, C. Ramos, I. Batista, J. A. Saraiva and M. L. Nunes, LWT - Food Science and Technology, 2014, 59, 533-539.

75. K. R. Badr, Z. S. Ahmed and M. S. El Gamal, International Journal of Agricultural Research, 2014, 9, 242-250.

76. S. Bahram, M. Rezaei, M. Soltani, A. Kamali, S. M. Ojagh and M. Abdollahi, Journal of Food Processing and Preservation, 2014, 38, 1251-1258.

77. A. C. Souza, G. E. O. Goto, J. A. Mainardi, A. C. V. Coelho and C. C. Tadini, LWT Food Science and Technology, 2013, 54, 346-352. 
78. I.-H. Kim, J. Han, J. H. Na, P.-S. Chang, M. S. Chung, K. H. Park and S. C. MNinticle online Journal of Food Science, 2013, 78, E229-E237.

79. I.-H. Kim, A. Y. Song, J. Han, K. H. Park and S. C. Min, Journal of Food Science, 2014, 79, E2023-E2030.

80. P. Montero-Prado, A. Rodriguez-Lafuente and C. Nerin, Postharvest Biology and Technology, 2011, 60, 211-219.

81. L. Gutiérrez, C. Sánchez, R. Batlle and C. Nerín, Trends in Food Science \& Technology, 2009, 20, 92-99.

82. S. M. Ojagh, M. Rezaei, S. H. Razavi and S. M. H. Hosseini, Food Chemistry, 2010, 122, 161-166.

83. S. Manso, D. Pezo, R. Gómez-Lus and C. Nerín, Food Control, 2014, 45, 101-108.

84. J. Wu, H. Liu, S. Ge, S. Wang, Z. Qin, L. Chen, Q. Zheng, Q. Liu and Q. Zhang, Food Hydrocolloids, 2015, 43, 427-435.

85. L. A. C. Zuanon, C. R. Malacrida and V. R. N. Telis, Journal of Food Process Engineering, 2013, 36, 364-373.

86. N.-B. Song, J.-H. Lee, M. Al Mijan and K. B. Song, LWT - Food Science and Technology, 2014, 57, 453-460.

87. P. R. Salgado, M. E. López-Caballero, M. C. Gómez-Guillén, A. N. Mauri and M. P. Montero, Food Hydrocolloids, 2013, 33, 74-84.

88. J. Gómez-Estaca, A. López de Lacey, M. E. López-Caballero, M. C. Gómez-Guillén and P. Montero, Food Microbiology, 2010, 27, 889-896.

89. K. Bentayeb, P. Vera, C. Rubio and C. Nerin, Analytical and Bioanalytical Chemistry, 2009, 394, 903-910.

90. W. X. Du, C. W. Olsen, R. J. Avena-Bustillos, T. H. McHugh, C. E. Levin and M. Friedman, Journal of Food Science, 2009, 74, M372-M378.

91. P. N. Takala, S. Salmieri, A. Boumail, R. A. Khan, K. D. Vu, G. Chauve, J. Bouchard and M. Lacroix, Journal of Food Engineering, 2013, 116, 648-655.

92. M. Bendahou, A. Muselli, M. Grignon-Dubois, M. Benyoucef, J.-M. Desjobert, A.-F. Bernardini and J. Costa, Food Chemistry, 2008, 106, 132-139.

93. M. Lahlou, Phytotherapy Research, 2004, 18, 435-448.

94. H. J. Jo, K. M. Park, S. C. Min, J. H. Na, K. H. Park and J. Han, Journal of Food Science, 2013, 78, E1713-E1720.

95. K. Chaieb, H. Hajlaoui, T. Zmantar, A. B. Kahla-Nakbi, M. Rouabhia, K. Mahdouani and A. Bakhrouf, Phytotherapy Research, 2007, 21, 501-506.

96. S. Burt, International Journal of Food Microbiology, 2004, 94, 223-253.

97. S. Kordali, A. Cakir, H. Ozer, R. Cakmakci, M. Kesdek and E. Mete, Bioresource Technology, 2008, 99, 8788-8795.

98. F. Sadaka, C. Nguimjeu, C.-H. Brachais, I. Vroman, L. Tighzert and J.-P. Couvercelle, Innovative Food Science \& Emerging Technologies.

99. M. Ramos, A. Jiménez, M. Peltzer and M. C. Garrigós, Food Chemistry, 2014, 162, 149-155.

100. F. Manzanarez-López, H. Soto-Valdez, R. Auras and E. Peralta, Journal of Food Engineering, 2011, 104, 508-517.

101. L. Bastarrachea, S. Dhawan and S. Sablani, Food Engineering Reviews, 2011, 3, 7993.

102. M. Ramos, E. Fortunati, M. Peltzer, F. Dominici, A. Jiménez, M. d. C. Garrigós and J. M. Kenny, Polymer Degradation and Stability, 2014, 108, 158-165.

103. M. F. Poças, J. C. Oliveira, F. A. R. Oliveira and T. Hogg, Critical Reviews in Food Science and Nutrition, 2008, 48, 913-928. 
104. A. Z. Graciano-Verdugo, H. Soto-Valdez, E. Peralta, P. Cruz-Zárate, A R. Istass ścle Online Rubio, S. Sánchez-Valdes, A. Sánchez-Escalante, N. González-Méndez and H. González-Ríos, Food Research International, 2010, 43, 1073-1078.

105. F. Iñiguez-Franco, H. Soto-Valdez, E. Peralta, J. F. Ayala-Zavala, R. Auras and N. Gámez-Meza, Journal of Agricultural and Food Chemistry, 2012, 60, 6515-6523.

106. M. Ramos, A. Beltrán, M. Peltzer, A. J. M. Valente and M. d. C. Garrigós, LWT Food Science and Technology, 2014, 58, 470-477.

107. K. K. Kuorwel, M. J. Cran, K. Sonneveld, J. Miltz and S. W. Bigger, LWT - Food Science and Technology, 2013, 50, 432-438.

108. J. H. Han, ed., Innovations in Food Packaging, Elsevier Academic Press, Canada, 2005.

109. M. Ramos, A. Beltran, A. Valdes, M. A. Peltzer, A. Jimenez and M. C. Garrigos, Journal of Bioequivalence \& Bioavailability, 2013, 5, 154-160.

110. H. M. C. Marques, Flavour and Fragrance Journal, 2010, 25, 313-326.

111. S. B. Schreiber, J. J. Bozell, D. G. Hayes and S. Zivanovic, Food Hydrocolloids, 2013, 33, 207-214.

112. J. Mastelic, I. Jerkovic, I. Blazevic, M. Poljak-Blazi, S. Borovic, I. Ivancic-Bace, V. Smrecki, N. Zarkovic, K. Brcic-Kostic, D. Vikic-Topic and N. Müller, Journal of Agricultural and Food Chemistry, 2008, 56, 3989-3996.

113. L. Barbosa-Pereira, J. M. Cruz, R. Sendón, A. Rodríguez Bernaldo de Quirós, A. Ares, M. Castro-López, M. J. Abad, J. Maroto and P. Paseiro-Losada, Food Control, 2013, 31, 236-243.

114. J. Hughes, R. Thomas, Y. Byun and S. Whiteside, Carbohydrate Polymers, 2012, 88, 165-172.

115. M. Jamshidian, E. Tehrany and S. Desobry, Food and Bioprocess Technology, 2013, 6, $1450-1463$.

116. M. C. Cruz-Romero, T. Murphy, M. Morris, E. Cummins and J. P. Kerry, Food Control, 2013, 34, 393-397.

117. M. V. Dias, V. Machado Azevedo, S. V. Borges, N. d. F. F. Soares, R. V. de Barros Fernandes, J. J. Marques and É. A. A. Medeiros, Food Chemistry, 2014, 165, 323-329.

118. C. M. Noronha, S. M. de Carvalho, R. C. Lino and P. L. M. Barreto, Food Chemistry, 2014, 159, 529-535.

119. G. Al-Bandak and V. Oreopoulou, European Journal of Lipid Science and Technology, 2007, 109, 247-255.

120. N. Didry, L. Dubreuil and M. Pinkas, Pharmaceutica Acta Helvetiae, 1994, 69, 25-28.

121. H. J. D. Dorman and S. G. Deans, Journal of Applied Microbiology, 2000, 88, 308316.

122. R. Shemesh, D. Goldman, M. Krepker, Y. Danin-Poleg, Y. Kashi, A. Vaxman and E. Segal, Journal of Applied Polymer Science, 2015, 132, n/a-n/a.

123. R. Efrati, M. Natan, A. Pelah, A. Haberer, E. Banin, A. Dotan and A. Ophir, Journal of Applied Polymer Science, 2014, 131, 40564.

124. L. Higueras, G. López-Carballo, P. Hernández-Muñoz, R. Catalá and R. Gavara, International Journal of Food Microbiology, 2014, 188, 53-59.

125. M. Kurek, A. Guinault, A. Voilley, K. Galić and F. Debeaufort, Food Chemistry, 2014, 144, 9-17.

126. M. López-Mata, S. Ruiz-Cruz, N. Silva-Beltrán, J. Ornelas-Paz, P. Zamudio-Flores and S. Burruel-Ibarra, Molecules, 2013, 18, 13735-13753.

127. M. Kurek, S. Moundanga, C. Favier, K. Galić and F. Debeaufort, Food Control, 2013, 32, 168-175. 
128. G. Kavoosi, S. M. M. Dadfar, A. Mohammadi Purfard and R. Mehrabi, Journkidf dfale Online Food Safety, 2013, 33, 423-432.

129. N. Khairuddin and I. I. Muhamad, Jurnal Teknologi, 2013, 62, 31-34.

130. Y. Wu, Y. Qin, M. Yuan, L. Li, H. Chen, J. Cao and J. Yang, Polymers for Advanced Technologies, 2014, 25, 948-954.

131. N. G. Sahib, F. Anwar, A.-H. Gilani, A. A. Hamid, N. Saari and K. M. Alkharfy, Phytotherapy Research, 2013, 27, 1439-1456.

132. F. Kayaci, H. S. Sen, E. Durgun and T. Uyar, Food Research International, 2014, 62 , 424-431.

133. K. K. Kuorwel, M. J. Cran, K. Sonneveld, J. Miltz and S. W. Bigger, Packaging Technology and Science, 2014, 27, 149-159.

134. K. A. Hammer, C. F. Carson and T. V. Riley, Journal of Applied Microbiology, 1999, 86, 985-990.

135. M. d. Rocha, M. R. Loiko, E. C. Tondo and C. Prentice, Food Hydrocolloids, 2014, 37, 213-220.

136. A. Júnior, N. Fronza, F. Foralosso, D. Dezen, E. Huber, J. dos Santos, R. Machado and M. Quadri, Food and Bioprocess Technology, 2014, 1-13.

137. A. Manab, M. E. Sawitri, K. U. Al Awwaly and H. Purnomo, African Journal of Food Science, 2011, 1, 6-11. 